\title{
1 A Direct Capture Method for Purification and Detection of Viral Nucleic Acid
} 2 Enables Epidemiological Surveillance of SARS-CoV-2

3

4
Subhanjan Mondal ${ }^{1, *}$, Nathan Feirer ${ }^{1}$, Michael Brockman, Melanie A. Preston, Sarah J. Teter, Dongping Ma, Said A. Goueli, Sameer Moorji, Brigitta Saul, James J. Cali

Promega Corporation, 5430 E Cheryl Pkwy, Fitchburg, WI, 53711.

Keywords: SARS-CoV-2, COVID-19, wastewater, wastewater-based epidemiology, RT-qPCR, nucleic acid purification

\footnotetext{
${ }^{1}$ Contributed equally to this work
}

\section{* Corresponding Author:}

Subhanjan Mondal

Email: subhanjan.mondal@promega.com

Address: Promega Corporation, 5430 E Cheryl Pkwy, Fitchburg, WI, 53711. 
medRxiv preprint doi: https://doi.org/10.1101/2021.05.06.21256753; this version posted May 10, 2021. The copyright holder for this preprint (which was not certified by peer review) is the author/funder, who has granted medRxiv a license to display the preprint in perpetuity.

It is made available under a CC-BY-ND 4.0 International license .

\section{Abstract}

47 Studies have demonstrated that SARS-CoV-2 RNA can be detected in the feces of infected individuals.

48 This finding spurred investigation into using wastewater-based epidemiology (WBE) to monitor SARS-

49 CoV-2 RNA and track the appearance and spread of COVID-19 in communities. SARS-CoV-2 is present

50 at low levels in wastewater, making sample concentration a prerequisite for sensitive detection and utility

51 in WBE. Whereas common methods for isolating viral genetic material are biased toward intact virus

52 isolation, it is likely that a relatively low percentage of the total SARS-CoV-2 RNA genome in

53 wastewater is contained within intact virions. Therefore, we hypothesized that a direct unbiased total

54 nucleic acid extraction method could overcome the cumbersome protocols, variability and low recovery rates associated with the former methods. This led to development of a simple, rapid, and modular alternative to existing purification methods. In an initial concentration step, chaotropic agents are added to

57 raw sewage allowing binding of nucleic acid from free nucleoprotein complexes, partially intact, and intact virions to a silica matrix. The eluted nucleic acid is then purified using manual or semi-automated methods. RT-qPCR enzyme mixes were formulated that demonstrate substantial inhibitor resistance. In addition, multiplexed probe-based RT-qPCR assays detecting the N1, N2 (nucleocapsid) and E (envelope)

61 gene fragments of SARS-CoV-2 were developed. The RT-qPCR assays also contain primers and probes

62 to detect Pepper Mild Mottle Virus (PMMoV), a fecal indicator RNA virus present in wastewater, and an

63 exogenous control RNA to measure effects of RT-qPCR inhibitors. Using this workflow, we monitored

64 wastewater samples from three wastewater treatment plants (WWTP) in Dane County, Wisconsin. We

65 also successfully sequenced a subset of samples to ensure compatibility with a SARS-CoV-2 amplicon

66 panel and demonstrated the potential for SARS-CoV-2 variant detection. Data obtained here underscore

67 the potential for wastewater surveillance of SARS-CoV-2 and other infectious agents in communities. 
medRxiv preprint doi: https://doi.org/10.1101/2021.05.06.21256753; this version posted May 10, 2021. The copyright holder for this preprint (which was not certified by peer review) is the author/funder, who has granted medRxiv a license to display the preprint in perpetuity.

It is made available under a CC-BY-ND 4.0 International license.

71

72 In late December of 2019, Chinese health authorities examined a new respiratory virus that caused

73 unexplained cases of severe pneumonia ${ }^{1}$. Subsequent sequencing identified the virus as a member of the

74 Coronavirus family, a group of enveloped RNA viruses that commonly infect birds, mammals, and

75 humans ${ }^{2}$. The novel virus, designated Severe Acute Respiratory Syndrome Coronavirus 2 (SARS-CoV-2),

76 is related to SARS-CoV and MERS-CoV, other respiratory viruses that can lead to fatal illness ${ }^{3}$. SARS-

77 CoV-2 was determined to be the causative agent of the respiratory disease COVID-19 ${ }^{1,4}$. COVID-19

78 quickly evolved into a global pandemic, which at the time of this report has resulted in over 3.1 million

79 deaths worldwide (https://coronavirus.jhu.edu/map.html).

80

81 The rapid person-to-person spread of SARS-CoV-2 is in part due to the high infectiousness of viral

82 carriers ${ }^{5,6}$. Pre-symptomatic shedding is thought to drive a significant amount of viral spread, as the

83 highest risk of transmission occurs very early in the course of the disease ${ }^{5,6}$. Asymptomatic carriers of the

84 virus are also infectious and display similar viral loads in the respiratory system, despite exhibiting faster

85 viral clearance ${ }^{6-9}$. As traditional nasal swab testing approaches can be biased towards symptomatic viral

86 carriers $^{10}$, viral surveillance methods that provide a widespread view of community infection are vital for

87 accurate monitoring and control of the ongoing pandemic.

88

89 Although infectious SARS-CoV-2 virions are rarely isolated from feces ${ }^{11}$, several reports early in the

90 COVID-19 pandemic demonstrated that SARS-CoV-2 can frequently (50\%-70\%) be detected in fecal

91 samples from both symptomatic and asymptomatic infected individuals ${ }^{9,12-15}$. Levels of SARS-CoV-2

92 RNA in feces are not correlated with the presence/absence of gastrointestinal illness or with overall

93 COVID-19 disease severity ${ }^{12}$, as is often the case with respiratory samples. Although SARS-CoV-2 viral

94 load is consistently higher in respiratory specimens, viral RNA in feces can be detected significantly 
medRxiv preprint doi: https://doi.org/10.1101/2021.05.06.21256753; this version posted May 10, 2021. The copyright holder for this preprint (which was not certified by peer review) is the author/funder, who has granted medRxiv a license to display the preprint in perpetuity.

It is made available under a CC-BY-ND 4.0 International license .

longer after initial symptom onset compared to nasal swab samples ${ }^{13,16}$. This aspect of SARS-CoV-2 fecal shedding could be a useful feature for assaying the levels of overall infection in a community.

One method that has been proposed for use in monitoring population-level rates of SARS-CoV-2 infection is wastewater-based epidemiology (WBE). WBE is the quantitative detection of chemical and biological signatures in wastewater to analyze the status of a human population in an area ${ }^{17}$. This approach has been used extensively in the past to characterize community usage/prevalence of illicit drugs such as cocaine, amphetamines, and opiates ${ }^{17}$. WBE detection methods have also been widely used to monitor the trends of circulating human pathogens in wastewater streams around the world ${ }^{17,18}$. Of particular relevance to SARS-CoV-2 are the efforts centering around environmental surveillance of the enteric viruses Poliovirus, Hepatitis A, and Norovirus ${ }^{19-21}$

In the Spring of 2020, research groups around the world started reporting the detection of SARS-CoV-2 RNA in untreated wastewater ${ }^{22-25}$ using quantitative reverse transcription PCR (RT-qPCR). SARS-CoV-2 RNA levels in wastewater positively correlated with clinical COVID-19 case numbers ${ }^{22}$. Several studies were able to demonstrate that an increasing trend of SARS-CoV-2 in wastewater preceded a rise in clinical cases by up to one week ${ }^{25-27}$, establishing the potential utility of COVID-19 WBE as an "early warning system" to mitigate viral spread and cost effective strategy for monitoring real-time changes in viral prevalence.

As viral concentrations in wastewater tend to be low, sample concentration is often a pre-requisite for sensitive detection and accurate quantitation. Concentration of viral matter can be performed using a variety of methods such as charged membrane filtration, centrifugal ultrafiltration, flocculation/precipitation using skimmed milk, and polyethylene glycol (PEG)/NaCl precipitation ${ }^{28}$. Most of the viral concentration methods described in the literature were originally developed to concentrate non-enveloped viral particles for use in downstream culture-based approaches, but they have been also 
medRxiv preprint doi: https://doi.org/10.1101/2021.05.06.21256753; this version posted May 10, 2021. The copyright holder for this preprint (which was not certified by peer review) is the author/funder, who has granted medRxiv a license to display the preprint in perpetuity.

It is made available under a CC-BY-ND 4.0 International license .

used for PCR detection. Many of these methods may work efficiently with several virus types but present

122 difficulties when applied to SARS-CoV-2. Notable issues have included inconsistent rates of viral

123 recovery after concentration, requirement for large sample sizes, and co-purification of PCR

124 inhibitors ${ }^{29,30}$. In addition, these viral concentration methods are labor intensive and time consuming,

125 requiring separate viral concentration and a nucleic acid extraction steps.

127 In this report, we describe the use of a novel column-based viral concentration and nucleic acid

128 purification system coupled to RT-qPCR detection for monitoring SARS-CoV-2 levels in wastewater.

129 The system allows for increased sample throughput due to the combination of viral purification and

130 nucleic acid purification steps. The effect of PCR inhibitors commonly found in wastewater is also

131 minimized. To demonstrate proof-of-concept, wastewater from three communities in Dane County,

132 Wisconsin was monitored for the presence of SARS-CoV-2 RNA over the course of three months. We

133 also successfully sequenced from a subset of samples to show compatibility with a commercially

134 available SARS-CoV-2 amplicon panel and demonstrated the potential for SARS-CoV-2 variant detection 135 from wastewater nucleic acid purified with the direct capture method.

\section{Methods}

140 Sample collection

141 Wastewater (untreated primary effluent) was collected from three wastewater treatment plants in Dane

142 County, Wisconsin: Oregon (WWTP-1), Madison (WWTP-2), Sun Prairie (WWTP-3). In all three

143 communities, the wastewater collection system is separate from the storm sewer system, minimizing the

144 dilution effect of precipitation events. 500-1000mL of a flow-paced (Oregon, Sun Prairie) or time-paced

145 (Madison) 24-hour composite sample were collected weekly using an autosampler (Madison: ISCO 
medRxiv preprint doi: https://doi.org/10.1101/2021.05.06.21256753; this version posted May 10, 2021. The copyright holder for this preprint (which was not certified by peer review) is the author/funder, who has granted medRxiv a license to display the preprint in perpetuity.

It is made available under a CC-BY-ND 4.0 International license .

FR3710; Sun Prairie: ISCO 5800; Oregon: ISCO 4700). Samples were kept at $4^{\circ} \mathrm{C}$ at all times during transport and storage. All samples were processed within six hours of sampling.

MS2 (ATCC 15597-B1) and Escherichia coli ATCC 15597 were purchased from American Type Culture Collection (ATCC) and propagated based on published methods ${ }^{31}$. The viral fraction in the culture supernatant was collected by centrifuging at $3500 \mathrm{x} g$ for 30 minutes to remove the bacterial fraction and filtered through a $0.22 \mu \mathrm{m}$ PES membrane filter. The purified MS2 virus $\left(\sim 10^{7} \mathrm{PFU} \mathrm{mL} \mathrm{mL}^{-1}\right)$ was stored at were then briefly mixed and nucleic acid extracted as described below.

\section{Isolation of Total Nucleic Acid from wastewater using the direct capture method}

Total nucleic acid (TNA) was purified from collected wastewater using the Wizard ${ }^{\circledR}$ Enviro Wastewater TNA kit (Promega Corp.) and/or the Maxwell ${ }^{\circledR}$ Enviro Wastewater TNA kit (Promega Corp.), both of which use an initial concentration step composed of direct capture of nucleic acids on silica resin. Briefly, $0.5 \mathrm{~mL}$ of alkaline protease was added to $40 \mathrm{~mL}$ of untreated wastewater in triplicate, and samples were incubated statically for 30 minutes at room temperature. The samples were then centrifuged at $3000 \times \mathrm{g}$

162 for 10 minutes to remove suspended solids. The supernatant was transferred to a new vessel and $12 \mathrm{~mL}$ of 163 Binding Buffer 1 and $1 \mathrm{~mL}$ of Binding Buffer 2 were added, followed by gentle mixing. A $48 \mathrm{~mL}$ of 164 isopropanol was added to the mixture, gently mixed and passed through a PureYield ${ }^{\mathrm{TM}}$ Midi Binding 165 Column (Promega Corp.) using a VacMan ${ }^{\circledR}$ Vacuum Manifold (Promega Corp.). Nucleic acid captured on the PureYield ${ }^{\mathrm{TM}}$ Midi Binding Column was washed with $5 \mathrm{~mL}$ of Column Wash 1 followed by $20 \mathrm{~mL}$ of Column Wash 2. Nucleic acid was eluted with nuclease-free water (Fig. 2). 
medRxiv preprint doi: https://doi.org/10.1101/2021.05.06.21256753; this version posted May 10, 2021. The copyright holder for this preprint (which was not certified by peer review) is the author/funder, who has granted medRxiv a license to display the preprint in perpetuity.

It is made available under a CC-BY-ND 4.0 International license .

171 Maxwell $^{\circledR}$ Enviro Wastewater TNA kit (Fig. 2). For the manual Wizard ${ }^{\circledR}$ Enviro Wastewater TNA kit,

$172400 \mu \mathrm{L}$ of Binding Buffer 1, $100 \mu \mathrm{L}$ of Binding Buffer 2 and $1.5 \mathrm{~mL}$ of isopropanol are added to the 1

$173 \mathrm{~mL}$ of nucleic acid extracted in the concentration step, and then passed through a spin column with a

174 silica resin. The column is washed with $350 \mu \mathrm{L}$ and $1 \mathrm{ml}$ of Column Wash 1 and 2 respectively, and

175 nucleic acid is extracted in $80 \mu \mathrm{L}$ of water. For the automated Maxwell ${ }^{\circledR}$ Enviro Wastewater TNA kit,

$176150 \mu \mathrm{L}$ of Binding Buffer 1 and $50 \mu \mathrm{L}$ of Binding Buffer 2 are added to $0.5 \mathrm{~mL}$ of nucleic acid extracted

177 in the concentration step. Then the total volume is added to well \#1 of the Maxwell ${ }^{\circledR}$ Cartridge and

178 nucleic acid is eluted in $80 \mu \mathrm{L}$ of nuclease-free water.

\section{Isolation of Total Nucleic Acid from suspended solids using the direct capture method}

The method to extract total nucleic acids from suspended solids is a variation on the direct capture methodology described above. After the alkaline protease step, the pellet of suspended solids is resuspended in $5 \mathrm{~mL}$ of nuclease-free water. To the resuspended pellet, $1.5 \mathrm{~mL}$ of Binding Buffer 1, 125 $\mu \mathrm{L}$ of Binding Buffer 2 and $6 \mathrm{~mL}$ of isopropanol were added and mixed. This step releases the nucleic acid bound to the solids into the suspension. The mixture was centrifuged at 3,000 $\mathrm{x} g$ for 10 minutes.

187 The supernatant contains the nucleic acid from the solids. The supernatant is then added to the

188 PureYield ${ }^{\mathrm{TM}}$ Midi Binding Column for the respective sample and treated independently as described 189 above.

\section{PEG/NaCl precipitation}

192 A sample of $120 \mathrm{~mL}$ of wastewater was centrifuged at $3000 \mathrm{x} g$ for 30 minutes to pellet any particulate

193 material. The supernatant was carefully decanted and then mixed with $12 \mathrm{~g}$ of PEG 8000 and $2.7 \mathrm{~g}$ of

$194 \mathrm{NaCl}$ that were dissolved by gentle mixing. Samples were then centrifuged at $11,400 \mathrm{x} g$ for two hours to 195 pellet viral material. The supernatant was carefully removed via pipetting on the side of the tube opposite 
medRxiv preprint doi: https://doi.org/10.1101/2021.05.06.21256753; this version posted May 10, 2021. The copyright holder for this preprint (which was not certified by peer review) is the author/funder, who has granted medRxiv a license to display the preprint in perpetuity.

It is made available under a CC-BY-ND 4.0 International license .

of that which the pellet was formed (pellet was not visible). The pellets were resuspended by vortexing with residual supernatant to a final volume of approximately $200 \mu \mathrm{L}$. Further nucleic acid purification was performed using Maxwell ${ }^{\circledR}$ RSC PureFood GMO and Authentication Kit (Promega Corp.) using the Maxwell ${ }^{\circledR}$ RSC Instrument (Promega Corp.) according to a modified version of manufacturer's protocol. Briefly, to $200 \mu 1$ of wastewater concentrate, $200 \mu \mathrm{L}$ of CTAB and $40 \mu \mathrm{L}$ of Proteinase $\mathrm{K}$ were added. Samples were vortexed, then incubated at $56^{\circ} \mathrm{C}$ for 10 minutes. The entire sample volume and $300 \mu \mathrm{L}$ of Lysis Buffer were added to well \#1 of the Maxwell ${ }^{\circledR}$ RSC cartridge. Nucleic acid was eluted with $50 \mu \mathrm{L}$ of Elution Buffer. Samples were processed on the Maxwell ${ }^{\circledR}$ RSC with the PureFood GMO and Authentication method.

\section{Oligonucleotides and quantification standards}

207 Table S1 lists the primers and probes used in this study, including primer and probe sets for the detection of SARS-CoV-2 (CDC-N1, CDC-N2, E_Sarbeco), PMMoV, and MS2 bacteriophage. The primers and probe for amplifying the luciferase $(l u c)$ gene for the internal amplification control are also listed. and the nucleocapsid gene (NCBI: 43740575) of SARS-CoV-2 into the pGEM-3z vector (Promega

213 Corp.) using the BamH I site. The plasmid was subsequently linearized using Xba I. The linearized 214 plasmid was in-vitro transcribed using T7 RiboMAX ${ }^{\mathrm{TM}}$ Large Scale RNA Production System (Promega 215 Corp.) to create Positive Control RNA. The linearized plasmid DNA containing the N and E genes, or the 216 in-vitro transcribed RNA were quantified using droplet digital PCR and used as a quantification control.

217 Linear quantification DNA and positive control RNA for PMMoV and MS2 were generated and 218 quantified using the same methods described above. 
medRxiv preprint doi: https://doi.org/10.1101/2021.05.06.21256753; this version posted May 10, 2021. The copyright holder for this preprint (which was not certified by peer review) is the author/funder, who has granted medRxiv a license to display the preprint in perpetuity.

It is made available under a CC-BY-ND 4.0 International license.

\section{RT-qPCR and quantification of viral load in wastewater}

222 TNA isolated from wastewater was used to perform RT-qPCR using the SARS-CoV-2 RT-qPCR

223 Detection Kit for Wastewater (Promega Corp.). RT-qPCR reactions targeted the nucleocapsid (N1, N2)

224 and envelope (E) regions of the SARS-CoV-2 genome. To allow for quantitation, $\log$ dilutions $\left(2 \times 10^{1}-\right.$

$2252 \times 10^{5}$ Genome Units $\left.(\mathrm{GU}) / \mu \mathrm{L}\right)$ of DNA quantitation standard were amplified alongside experimental

226 samples and used to construct a standard curve for each SARS-CoV-2 target. $20 \mu \mathrm{L}$ amplification

227 reactions were composed of $15 \mu \mathrm{L}$ reaction mastermix and $5 \mathrm{uL}$ of nucleic acid. $5 \mu \mathrm{L}$ of nuclease-free

228 water was used as a no-template-control (NTC). Reactions were performed on a Stratagene MX3005

229 Real-Time Thermocycler (Agilent) with the following cycling conditions: reverse transcription for 15

230 minutes at $45^{\circ} \mathrm{C}$, initial denaturation for 2 minutes at $95^{\circ} \mathrm{C}$, and 40 cycles of 3 seconds at $95^{\circ} \mathrm{C}$ and 30

231 seconds at $62^{\circ} \mathrm{C}$. Standard curve reactions were run in triplicate and wastewater sample reactions were

232 run in duplicate. The standard curve approach described above was used in parallel to estimate the

233 concentration of MS2 and PMMoV in purified samples.

234

235 Concentration of viral load in wastewater was calculated using the equation:

236

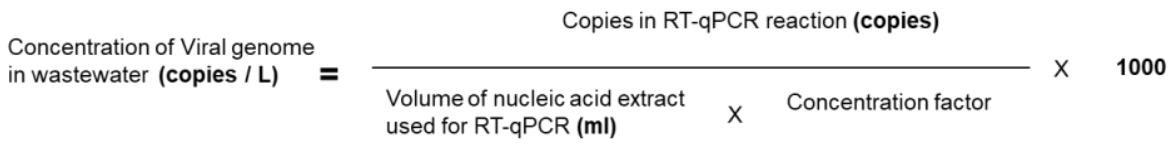

$$
\text { Concentration factor }=\frac{\text { Wastewater sample volume used }(\mathrm{ml})}{\text { Volume of nucleic acid extracted }(\mathrm{ml})}
$$

241 Normalization of SARS CoV-2 amounts in wastewater was performed by using the following equation:

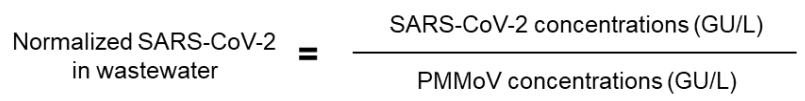


medRxiv preprint doi: https://doi.org/10.1101/2021.05.06.21256753; this version posted May 10, 2021. The copyright holder for this preprint (which was not certified by peer review) is the author/funder, who has granted medRxiv a license to display the preprint in perpetuity.

It is made available under a CC-BY-ND 4.0 International license.

\section{Statistical analysis}

245 Concordance between trend analysis using the three SARS-CoV-2 targets (N1, N2 and E) was evaluated 246 using Kendall's coefficient of concordance (W). Correlation between weekly normalized SARS-CoV-2

247 levels from wastewater and number of new clinical cases (7 day moving average) was determined using

248 Kendall's tau correlation coefficient.

\section{SARS-CoV-2 amplicon library preparation and sequencing}

$25110 \mu \mathrm{L}$ of each total nucleic acid sample was treated for 30 minutes at $37^{\circ} \mathrm{C}$ with $1.5 \mathrm{U}$ of RQ1 RNase-

252 Free DNase (Promega Corporation) in a $15 \mu \mathrm{L}$ reaction, as specified in the manufacturer's protocol, 253 except that the Stop Solution provided was not used. $10 \mu \mathrm{L}$ of nuclease-free water was added to each 254 sample and cleaned up with the ReliaPrep ${ }^{\mathrm{TM}}$ RNA Clean-Up and Concentration System (Promega 255 Corporation), as specified in the manufacturer's technical manual. RNA was eluted with $15 \mu \mathrm{L}$ of 256 nuclease-free water.

cDNA was synthesized as follows. $10 \mu \mathrm{L}$ of either total nucleic acid sample or DNase-treated sample was used as a template for first strand synthesis with random hexamers and associated steps using Invitrogen $^{\mathrm{TM}}$ SuperScript ${ }^{\mathrm{TM}}$ IV First-Strand Synthesis System (Thermo Fisher Scientific). Manufacturer's instructions were followed with one exception: incubation time at $50^{\circ} \mathrm{C}$ was increased from 10 minutes to 30 minutes, as recommended by the Swift Biosciences SARS-CoV-2 Additional Genome Coverage amplicon panel library preparation protocol.

$10 \mu \mathrm{L}$ of cDNA was used as input for the SARS-CoV-2 Additional Genome Coverage panel (Swift Biosciences) using the low input version of the library preparation protocol. This 345 -amplicon panel

267 covers $99.7 \%$ of the SARS-CoV-2 genome and has amplicons ranging from 116 to 255 bp (average 150

268 bp). Libraries were quantified by qPCR, pooled, and sequenced with $2 \times 150$ base-pair reads on an 
medRxiv preprint doi: https://doi.org/10.1101/2021.05.06.21256753; this version posted May 10, 2021. The copyright holder for this preprint (which was not certified by peer review) is the author/funder, who has granted medRxiv a license to display the preprint in perpetuity.

It is made available under a CC-BY-ND 4.0 International license .

271 Amplicon sequencing analysis

272 Compressed, demultiplexed reads were obtained from the Illumina MiniSeq instrument and assessed for

273 sequencing quality using FastQC 0.11.9-0

274 (https://www.bioinformatics.babraham.ac.uk/projects/fastqc/). For the purpose of comparing

275 performance between libraries, random subsampling was performed to obtain the same number of input

276 reads for each library using seqtk v1.2. All available reads for each library were used in known variant

277 detection. Adapter trimming was done using Fastp v0.20.1 ${ }^{32}$ (sequences

278 AGATCGGAAGAGCACACGTCTGAACTCCAGTCA and

279 AGATCGGAAGAGCGTCGTGTAGGGAAAGAGTGT). Trimmed reads were mapped to the SARS-

280 CoV-2 reference genome (NC_045512.2) using BWA v 0.7.17. To assess human genomic contribution,

281 trimmed reads were also mapped to a combined SARS-CoV-2 + GRCh38/hg38 ${ }^{33}$ (UCSC Genome

282 Browser ${ }^{34}$ Dec 2013 assembly) reference genome. Amplicon primers were trimmed following alignment

283 using Swift's Primerclip tool v 0.3 .8 (https://github.com/swiftbiosciences/primerclip) with the Swift-

284 provided master file for the 345 amplicon panel as input. QC metrics were generated using Picard (v

285 2.9.2; http://broadinstitute.github.io/picard) BedToIntervalList, CollectTargetedPcrMetrics,

286 CollectGcBiasMetrics. The GATK $3^{35}$ DepthOfCoverage tool was used for target base coverage

287 assessments (median, mean, percent of bases at or above 1X,100X, 1000X, and 5000X). Snakemake

288 v5.17.0 was used for workflow management on a Microsoft Azure CycleCloud instance.

Detection of known signature variants

291 Genomic locations of known signature variants were obtained from Nextstrain ${ }^{36}$ (accessed 12 March

292 2021) and UCSC Table Browser ${ }^{37}$ (SARS-CoV-2 Jan. 2020/NC_045512.2 Assembly (wuhCor1)) and

293 formatted into a BED file. With aligned, primer-trimmed reads in BAM format, the bam-readcount tool

294 (https://github.com/genome/bam-readcount) was used to collect base composition information at the 
medRxiv preprint doi: https://doi.org/10.1101/2021.05.06.21256753; this version posted May 10, 2021. The copyright holder for this preprint (which was not certified by peer review) is the author/funder, who has granted medRxiv a license to display the preprint in perpetuity.

It is made available under a CC-BY-ND 4.0 International license .

signature variant locations. The bam-readcount output was filtered to look for the presence of signature variants with at least $10 \%$ frequency at positions covered to at least $50 \mathrm{X}$, so that no signature variant would be called as detected with fewer than 5 sequencing reads as evidence.

Results

\section{RT-qPCR Reaction Formulation and Setup}

302 Operating under the assumption that wastewater is likely to contain RT-qPCR inhibitors, we formulated enzyme mixes containing MMLV-RT enzyme and Taq DNA polymerase (with hot-start chemistry) that would be resistant to PCR inhibitors. Next, we designed separate multiplexed RT-qPCR assays to detect the nucleocapsid gene fragment N1 and N2 (as described by the CDC: https://www.cdc.gov/coronavirus/2019-ncov/lab/rt-pcr-panel-primer-probes.html) and the envelope gene

307 (as described by Corman et al. ${ }^{38}$ ). SARS-CoV-2 targets were detected using primers and a target-specific Mottle Virus (PMMoV). PMMoV is a single-stranded RNA plant virus that commonly infects pepper

311 products intended for human consumption ${ }^{39}$. PMMoV RNA is detectable in wastewater worldwide and is

312 considered an important indicator of human-derived fecal pollution ${ }^{40-42}$. Each assay also includes an

313 exogenous RNA template, primers and hydrolysis probe (labeled with 5' CalFluor ${ }^{\circledR}$ Orange 560/ $\mathrm{BHQ}^{\circledR}-1$ )

314 comprising an internal amplification control (IAC). The IAC's cycle threshold (Ct) provides information

315 on the presence of reverse transcriptase and DNA polymerase inhibitors in the extracted nucleic acid

316 sample. CXR, (Carboxy-X-Rhodamine, Promega Corp.) which has similar spectral properties as ROX

317 (Ex: 580nm, Em: 602nm) was used as a reference dye.

319 We sought to optimize an appropriate amplicon length from the IAC template to provide sufficient sensitivity to detect RT-qPCR inhibition. An in vitro transcribed Luciferase RNA (Promega Corp.) was 
medRxiv preprint doi: https://doi.org/10.1101/2021.05.06.21256753; this version posted May 10, 2021. The copyright holder for this preprint (which was not certified by peer review) is the author/funder, who has granted medRxiv a license to display the preprint in perpetuity.

It is made available under a CC-BY-ND 4.0 International license .

321 used as a template and four different amplicon lengths ( $93 \mathrm{bp}, 285 \mathrm{bp}, 310 \mathrm{bp}$ and 435bp) were tested.

322 Humic acid, a known reverse transcriptase and DNA polymerase inhibitor ${ }^{43}$, was titrated from $0 \mu \mathrm{g} / \mathrm{mL}$

323 to $125 \mu \mathrm{g} / \mathrm{mL}$ using a two-fold dilution series, and inhibition was assessed by the difference in $\mathrm{Ct}$ value

324 with or without humic acid $(\Delta \mathrm{Ct})$. The same hydrolysis probe was used in all cases. As expected, we

325 found a correlation between the amplicon length and sensitivity to humic acid (Fig. 1A), with the 435 bp

326 and $315 \mathrm{bp}$ amplicons exhibiting higher $\Delta \mathrm{Ct}$ values compared to the $285 \mathrm{bp}$ and $93 \mathrm{bp}$ amplicons. Since

327 the RT-qPCR amplicons for detection of SARS-CoV-2 and PMMoV are below 150 bp in length and the

$328 \Delta \mathrm{Ct}$ values for $285 \mathrm{bp}$ and $93 \mathrm{bp}$ amplicons were similar, the $285 \mathrm{bp}$ amplicon length was used as IAC

329 unless otherwise specified.

330

331 For WBE, it is important to quantify the viral genome units per volume of wastewater to determine the

332 quantitative trend in viral load. To analyze the analytical sensitivity, efficiency, and linearity of the assay,

333 a log dilution series of the in-vitro transcribed SARS-CoV-2 RNA (N and E) was used to perform RT-

334 qPCR analysis. PCR amplification efficiencies for all three targets were between 90-120\%. The limit of

335 detection (LOD 95 ) for the three multiplexed assays for detecting the SARS-CoV-2 targets was 5 copies

336 and a limit of quantification (LOQ) of 8 copies. The RT-qPCR assays are linear in the tested range of 20-

337200,0000 copies, as the observed $R^{2}$ for all the three targets were $\geq 0.99$ (Fig. 1B).

338 The assay was also tested for specificity with other coronaviruses and respiratory pathogens. The assay

339 was found to be specific for detection of SARS-CoV-2 and PMMoV (Table S2). 


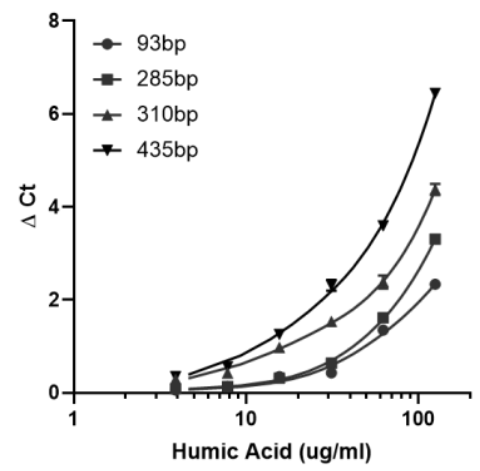

B

\begin{tabular}{cccccc}
\hline Assay & Slope & $y$-intercept & $\mathbf{R}^{2}$ & Efficiency (\%) & $\begin{array}{c}\text { LOD }_{95} \\
\text { (no. of copies) }\end{array}$ \\
\hline N1 & -3.344 & 39.97 & 0.989 & 99.2 & 5 \\
N2 & -3.289 & 39.81 & 0.995 & 101.9 & 5 \\
E & -3.412 & 40.31 & 0.994 & 95.8 & 5 \\
\hline
\end{tabular}

Figure 1. (A) Optimization of Internal Amplification Control (IAC) amplicon size for

\section{Description of the direct-nucleic acid capture method}

349 Existing literature suggests that SARS-CoV-2 may not be infectious in wastewater samples ${ }^{44,45}$. It is therefore unknown if the viral genetic signature present in the wastewater samples is entirely derived from compromised virions or if some proportion is present as unpackaged SARS-CoV-2 nucleic acid. We hypothesized that by utilizing a direct capture method to bind total nucleic acid (TNA) to a silica-based affinity resin in place of a method that is selective for intact viral particles, we may be able to eliminate the viral concentration step which is often a cause of technical variability and low recovery. Direct TNA isolation would be unbiased toward intact, partially intact, or free viral RNA. We developed a simple, 
medRxiv preprint doi: https://doi.org/10.1101/2021.05.06.21256753; this version posted May 10, 2021. The copyright holder for this preprint (which was not certified by peer review) is the author/funder, who has granted medRxiv a license to display the preprint in perpetuity.

It is made available under a CC-BY-ND 4.0 International license .

primary concentration method utilizes raw sewage, to which chaotropic agents are added to allow binding on to a silica matrix (PureYield ${ }^{\mathrm{TM}}$ Midi Binding column) by applying vacuum. The captured nucleic acid

359 is then subjected to successive alcohol washes (to remove RT-qPCR inhibitors that may have co-purified

360 with the nucleic acid) and subsequently eluted in water (Fig. 2). The eluted nucleic acid can then be

361 further processed in a second step with either a spin column with Wizard ${ }^{\circledR}$ Enviro Wastewater TNA kit or with an automated nucleic acid purification system for the Maxwell ${ }^{\circledR}$ RSC Enviro Wastewater TNA kit (Fig. 2).

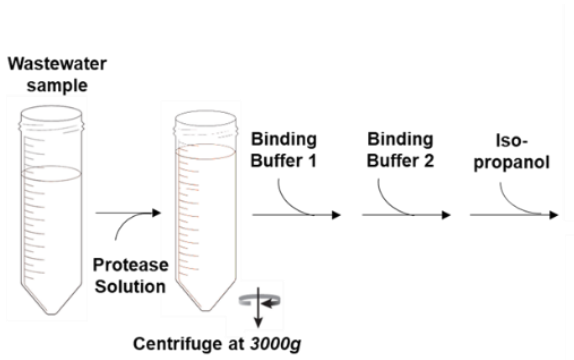

\section{Step 1: Concentration}
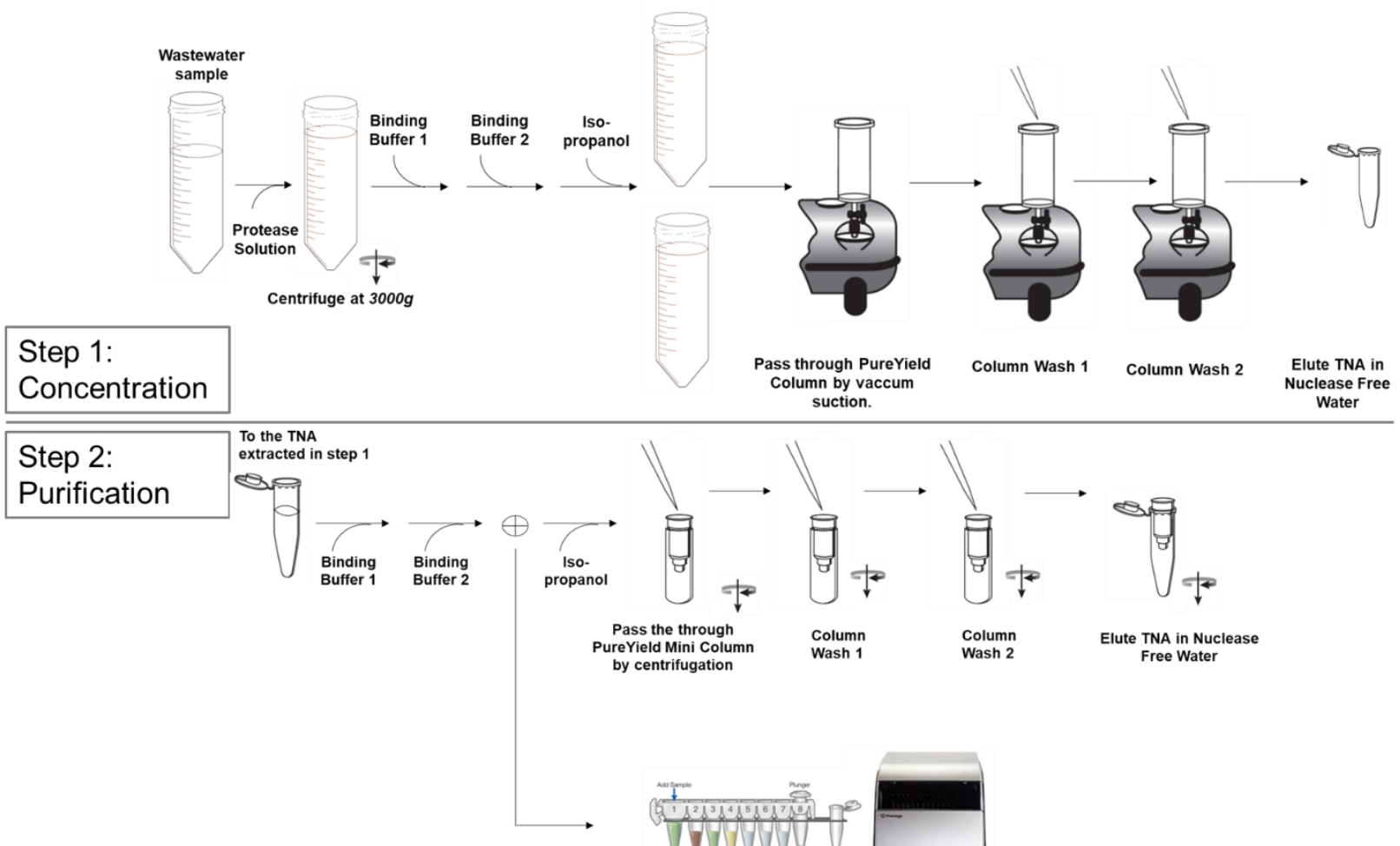

Figure 2. Schematic overview of the direct capture nucleic acid purification process.

367 The direct-nucleic acid capture method was first tested for its ability to eliminate RT-qPCR inhibitors. Inhibition was analyzed by comparing the difference in $\mathrm{Ct}$ value $(\Delta \mathrm{Ct})$ between IAC amplification in reactions for wastewater sample and for no-template-control (NTC) reactions. The $\Delta \mathrm{Ct}$ values were 
medRxiv preprint doi: https://doi.org/10.1101/2021.05.06.21256753; this version posted May 10, 2021. The copyright holder for this preprint (which was not certified by peer review) is the author/funder, who has granted medRxiv a license to display the preprint in perpetuity.

It is made available under a CC-BY-ND 4.0 International license .

370 analyzed for samples processed using either the primary concentration step with the PureYield ${ }^{\mathrm{TM}}$ Midi

371 column only or processed through the complete workflow comprising the Wizard $^{\circledR}$

372 concentration/purification steps outlined above. $\Delta \mathrm{Ct}$ values $>1$ indicated the presence of reverse

373 transcriptase and/or DNA polymerase inhibitors in the wastewater samples added to the RT-qPCR

374 reaction. $\Delta \mathrm{Ct}$ values of $<1$ were observed for both nucleic acid purified with the PureYield ${ }^{\mathrm{TM}}$ Midi

375 column only and samples purified with both ${ }^{\text {TM }}$ Midi and PureYield ${ }^{\text {TM }}$ Mini column steps (Fig. 3A). In the

376 second step, total nucleic acid eluted from the first step is further purified in a smaller volume $(80 \mu \mathrm{L})$,

377 concentrating the nucleic acid by 12.5 -fold. This concentration is evident when MS2 (viral spike-in

378 control) or SARS-CoV-2 (N1) is analyzed, as we observed a 8.34- and 5.54- fold increase in the amount

379 of MS2 and SARS-CoV-2 RNA detected, relative to the sample that only underwent initial sample

380 concentration (Fig. 3B and C). This indicates that the second purification step successfully concentrates

381 the nucleic acid in the sample.

382 Different laboratories have different throughput needs. Because our workflow can be done manually or

383 using automation for the final sample concentration, it provides flexibility for different types of labs. This

384 flexibility allows scale-up of the nucleic acid concentration process using an automated nucleic acid

385 purification workflow after the initial concentration step using the PureYield ${ }^{\mathrm{TM}}$ Midi column. We

386 compared the extraction efficiency of the nucleic acid isolated by either the manual spin column (Wizard ${ }^{\circledR}$

387 Enviro Wastewater TNA kit) or with an automated nucleic acid purification system for the Maxwell ${ }^{\circledR}$

388 RSC Enviro Wastewater TNA kit. Purified concentrations of PMMoV, MS2 (viral spike), and SARS-

389 CoV-2 RNA were similar with both purification methods (Fig. 3D). These data indicate that both manual

390 and automated nucleic acid purification procedures can be used to extract viral genetic material at similar

391 extraction efficiencies. 
A

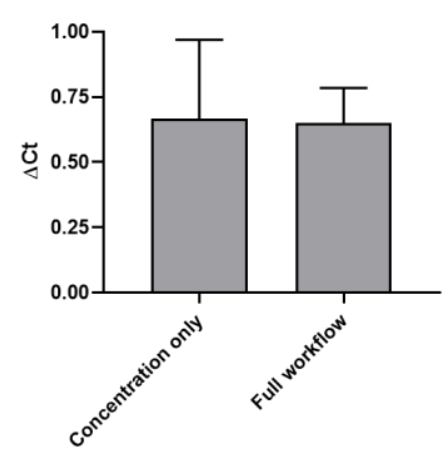

D

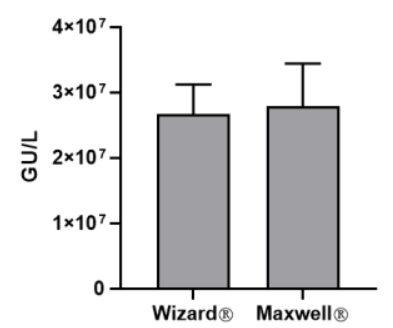

B

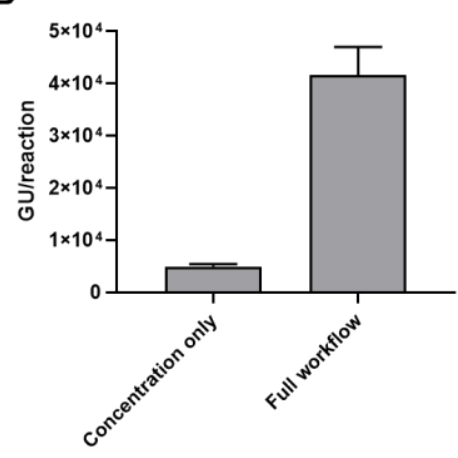

MS2

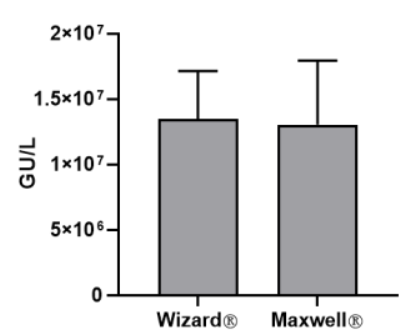

C

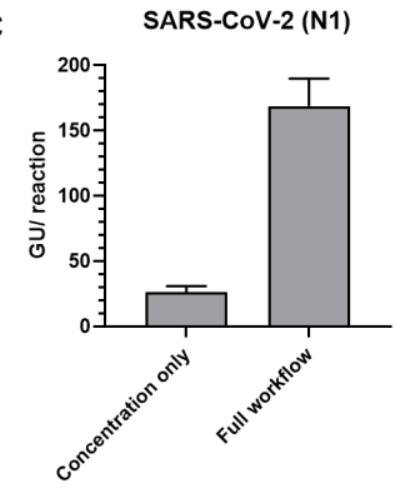

SARS-CoV-2 (N1)

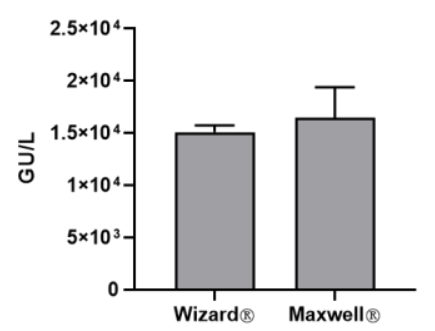

Figure 3. (A) The direct capture method can reduce presence of RT-qPCR inhibitors

present in extracted samples. "Full workflow" refers to the combination of

the NTC wells compared to sample wells. Viral concentrations detected via RT-qPCR MS2 and SARS-COV-2. Results shown are means $\pm \operatorname{SD}(n=3)$

\section{Sample volume considerations}

404 SARS-CoV-2 levels in wastewater are often very low, making sample concentration from a larger volume

405 a necessary part of any WBE monitoring workflow. To determine what starting sample volume allows for

406 convenient and sensitive viral detection, we processed different volumes of wastewater $(80 \mathrm{~mL}, 40 \mathrm{~mL}$,

$40720 \mathrm{~mL}, 10 \mathrm{~mL}$, and $5 \mathrm{~mL}$ ) using the column-based manual concentration/purification scheme (Wizard $\left.{ }^{\circledR}\right)$ 
medRxiv preprint doi: https://doi.org/10.1101/2021.05.06.21256753; this version posted May 10, 2021. The copyright holder for this preprint (which was not certified by peer review) is the author/funder, who has granted medRxiv a license to display the preprint in perpetuity.

It is made available under a CC-BY-ND 4.0 International license .

outlined above and performed all final elutions in the same volume $(80 \mu \mathrm{L})$ of nuclease-free water. The adjusted volumes of Protease solution, binding buffers 1 and 2 and isopropanol used for each starting volume are outlined in Fig. 4A. MS2 bacteriophage was used as a viral spike-in recovery control.

The shift in Ct values from the NTC reactions $(\Delta \mathrm{Ct})$ for the IAC exhibited a sample volume-dependent increase in $\mathrm{Ct}$ value indicating a higher concentration of inhibitors may be co-purifying when larger volumes are used. However, the $\Delta \mathrm{Ct}$ was $<1 \mathrm{Ct}$ for all the volumes tested, indicating co-purification of

414 RT-PCR inhibitors was not high enough to significantly impact data interpretation (Fig 4B). We also analyzed the amounts of PMMoV, MS2 and SARS-CoV-2 (N1). As expected, all targets showed a are high, use of $40 \mathrm{ml}$ sample volume will allow sufficient assay sensitivity when viral loads are lower.

A

\begin{tabular}{ccccc}
\hline $\begin{array}{c}\text { Sample volume } \\
(\mathbf{m l})\end{array}$ & $\begin{array}{c}\text { Alk Protease } \\
(\mathbf{m l})\end{array}$ & $\begin{array}{c}\text { Binding Buffer } \\
\mathbf{1}(\mathbf{m l})\end{array}$ & $\begin{array}{c}\text { Binding Buffer 2 } \\
(\mathbf{m l})\end{array}$ & $\begin{array}{c}\text { Isopropanol } \\
(\mathbf{m l})\end{array}$ \\
\hline 5 & 0.1 & 1.5 & 0.125 & 6 \\
10 & 0.125 & 3 & 0.25 & 12 \\
20 & 0.25 & 6 & 0.5 & 24 \\
40 & 0.5 & 12 & 1 & 48 \\
80 & 1 & 24 & 2 & 96 \\
\hline
\end{tabular}

B
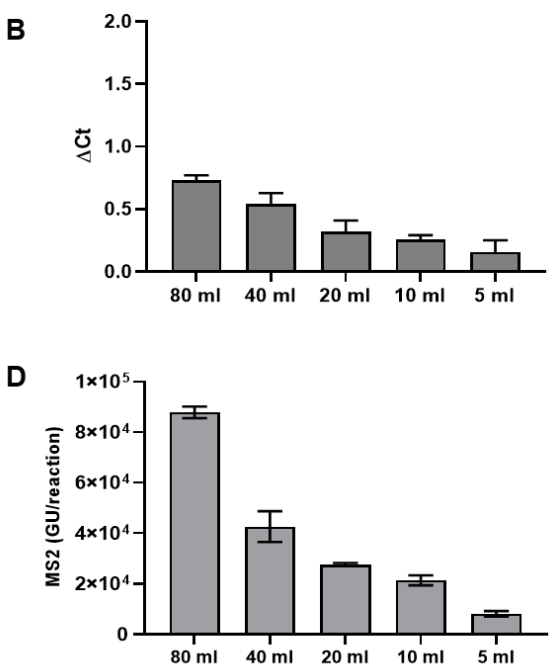

C

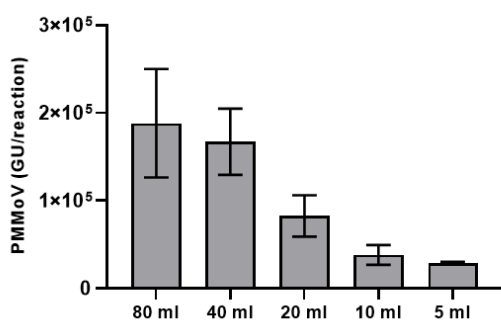

E

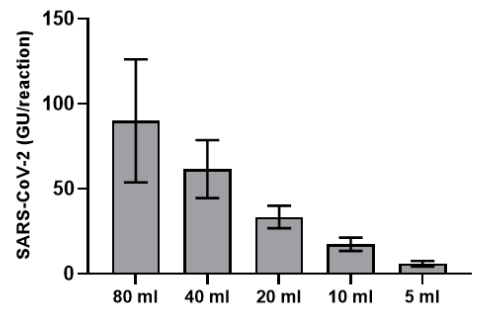

$\mathbf{F}$

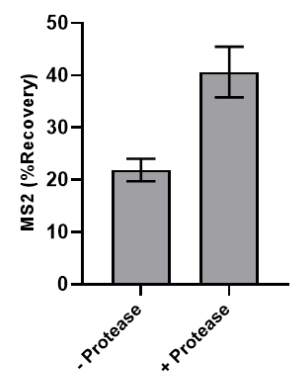

G

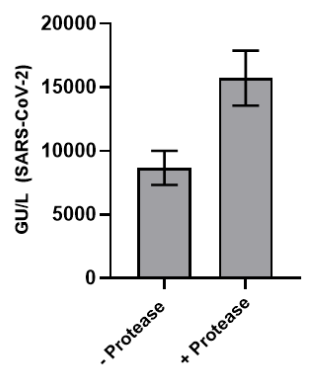


medRxiv preprint doi: https://doi.org/10.1101/2021.05.06.21256753; this version posted May 10, 2021. The copyright holder for this preprint (which was not certified by peer review) is the author/funder, who has granted medRxiv a license to display the preprint in perpetuity.

It is made available under a CC-BY-ND 4.0 International license .

421

422

423

424

425

426

427

428

429

430

431

432

433

434

435

436

437

438

439

440

441

442

443

444

445

446

Figure 4. Sample volume considerations. (A) Volumes of reagents required for different sample volumes. (B) Increasing the sample volume from $5 \mathrm{ml}$ to $80 \mathrm{ml}$ does not lead to significant inhibition of RT-qPCR performance as measured using the Internal amplification control (IAC). DCt represents the difference in Ct values of samples compared to the NTC reactions. (C-E) Increase in the amount of viral genetic material extracted as sample volume is increased as measured by RT-qPCR detection of PMMoV (C), MS2 (D) and SARS-CoV-2 (E). Extraction efficiency of MS2 (F) and SARS-CoV-2 (G) genetic material from wastewater samples with and without protease treatment. Results shown are means $\pm \operatorname{SD}(n=3)$.

\section{Enhancement of viral nucleic acid recovery with protease treatment}

Wastewater, in addition to containing fecal matter and water, is also composed of cellulosic material from toilet and tissue paper that may act as a substrate on which nucleic acids and nucleoprotein complexes can aggregate. This material may form a large part of the suspended solids present in wastewater. SARSCoV-2 may not be present as intact virions in wastewater, but the observation that the genetic material is readily detectable indicates that the viral RNA is likely present in ribonucleoprotein complexes, which shield it from nucleases that are presumably present in wastewater. In addition, detergents and chaotropic agents present in wastewater may also cause structural changes to proteins causing association with suspended solids. Therefore, we reasoned that a proteolytic cleavage step may be able to release some of the viral genetic material associated with solids.

We measured viral nucleic acid extraction efficiency using a procedure that included alkaline protease treatment. $40 \mathrm{~mL}$ wastewater samples were either treated with alkaline protease or left untreated and processed as described in the Methods section. MS2 phage was also spiked into the samples. Percent recoveries of MS2 nucleic acid were found to be $20 \%$ for untreated samples and $40 \%$ for samples that were treated with alkaline protease (Fig. 4F). Similarly, we also observed a two-fold increase in extraction of SARS-CoV-2 viral genome units when samples were treated with protease (Fig. 4G). These 
medRxiv preprint doi: https://doi.org/10.1101/2021.05.06.21256753; this version posted May 10, 2021. The copyright holder for this preprint (which was not certified by peer review) is the author/funder, who has granted medRxiv a license to display the preprint in perpetuity.

It is made available under a CC-BY-ND 4.0 International license .

447 results indicate that alkaline protease treatment increases yield of viral TNA extraction, most likely by

448 releasing a portion of the viral genomic material associated with suspended solids.

\section{Amount of viral matter associated with solids}

451 In the purification workflow described above, suspended solids are removed via a brief centrifugation

452 following the alkaline protease treatment step. Removing suspended solids prevents clogging of the

453 PureYield ${ }^{\mathrm{TM}}$ Midi column. We investigated how much viral matter is associated with the pelleted solids

454 using the procedure described in the methods section. The eluted nucleic acid was analyzed for the

455 quantity of PMMoV and SARS-CoV-2 RNA. We observed that about $11.79 \%$ of the total amount of

456 PMMoV and 19.27\% of the total amount of SARS-CoV-2 genetic material associated with the solids

457 (Fig. 5A-B). If maximal nucleic acid yield is desired, the solids-associated supernatant fraction can be combined with the wastewater supernatant fraction to purify nucleic acid from the total pooled sample.

A

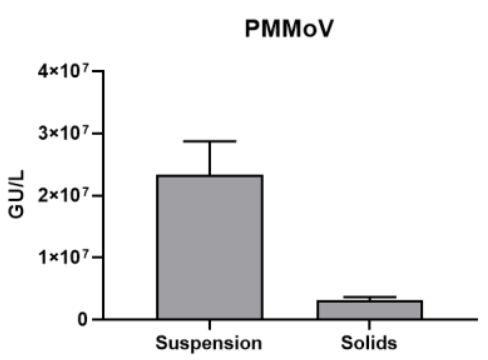

B

SARS-CoV-2 (N1)

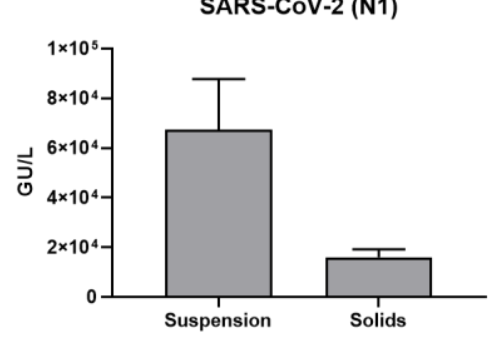

Figure 5. Amount of viral matter associated with solids after protease treatment. 
medRxiv preprint doi: https://doi.org/10.1101/2021.05.06.21256753; this version posted May 10, 2021. The copyright holder for this preprint (which was not certified by peer review) is the author/funder, who has granted medRxiv a license to display the preprint in perpetuity.

It is made available under a CC-BY-ND 4.0 International license .

Concentrations of PMMOV (A) and SARS-CoV-2 (B) RNA present in the two fractions as

measured by RT-qPCR are shown. Results shown are means $\pm \operatorname{SD}(n=3)$.

\section{Comparison of viral nucleic acid recovery: Direct Capture method vs PEG/NaCl precipitation}

467 Using the optimized method described above, we compared the direct capture method with PEG/NaCl

468 precipitation method for the ability to purify SARS-CoV-2 genetic material from wastewater samples.

$469 \mathrm{PEG} / \mathrm{NaCl}$ is a widely used method for precipitation and concentration of non-enveloped enteric virus

470 such as Poliovirus ${ }^{28} .40 \mathrm{~mL}$ of wastewater sample was processed for the direct capture method and 120

$471 \mathrm{~mL}$ of wastewater was processed using $\mathrm{PEG} / \mathrm{NaCl}$ precipitation. We observed a 20 -fold increased

472 extraction efficiency for extracting SARS-CoV-2 RNA (Fig. 6A) when using the direct capture method

473 compared to the PEG/NaCl protocol. For MS2 (viral spike control) we observed an extraction efficiency

474 of $3.76 \pm 1.88 \%$ for the PEG/NaCl method and $39.67 \pm 10.66 \%$ for the direct capture method (Fig $6 \mathrm{~B}$ ).

475 We also determined the percentage recovery for two human coronaviruses (OC43 and 229E) for the direct

476 capture method and they were $63.13 \pm 4.16 \%, 40.09 \pm 10.89 \%$ respectively (data not shown).

477 The direct capture purification workflow utilizing $40 \mathrm{ml}$ of wastewater sample and a 40ul elution volume

478 has a concentration factor of 1000. With a LOD of 5 copies for the detection of SARS-CoV-2 by RT-

479 qPCR reaction, and 1000-fold concentration in the purification process, the assay sensitivity is around 1

480 viral genome copies/ml. This level of sensitivity will be sufficient for trend analysis using WBE. 


\section{A}

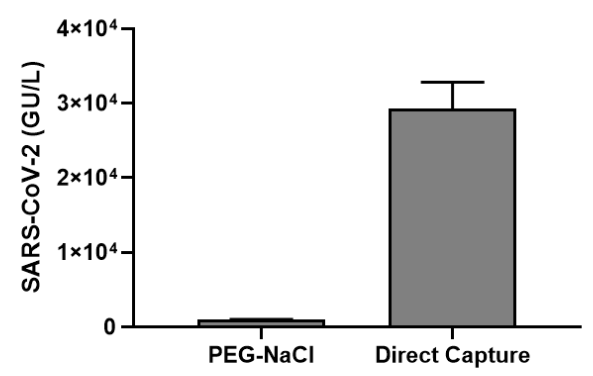

B

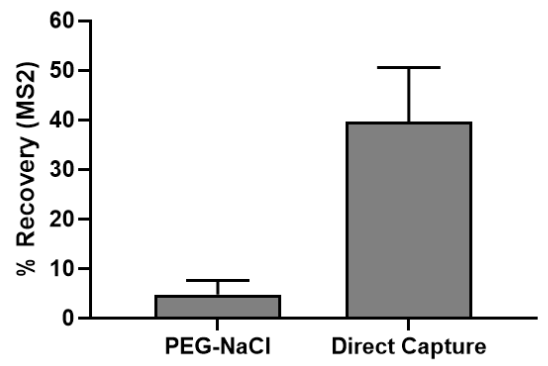

Figure 6. Comparison of the direct capture method with PEG/NaCl precipitation. Wastewater samples were processed using the two methods as described in the Methods section. (A) Concentration of SARS-CoV-2 RNA extracted is represented as GU/L in the control). Results shown are means $\pm \operatorname{SD}(n=3)$.

\section{SARS-CoV-2 RNA in wastewater from Dane County, Wisconsin}

489 The levels of SARS-CoV-2 RNA from three wastewater treatment plants in Dane County, Wisconsin

490 from mid-October, 2020 to early January, 2021 were determined using the Wizard ${ }^{\circledR}$ Enviro Wastewater

491 TNA kit described above. Samples were processed and analyzed weekly. The levels of RT-qPCR

492 inhibitors present in the TNA samples (as assessed by shift in the $\mathrm{Ct}$ value $(\Delta \mathrm{Ct})$ of IAC in sample wells

493 compared to NTC wells) were not notable, as $\Delta \mathrm{Ct}$ values were less than 0.5 for all wastewater samples

494 (Fig. 7A). 
medRxiv preprint doi: https://doi.org/10.1101/2021.05.06.21256753; this version posted May 10, 2021. The copyright holder for this preprint (which was not certified by peer review) is the author/funder, who has granted medRxiv a license to display the preprint in perpetuity.

It is made available under a CC-BY-ND 4.0 International license.

We analyzed SARS-CoV-2 RNA levels using N1, N2, and E targets (Fig. 7B). All samples were positive

for all three SARS-CoV-2 targets within the period tested. We calculated the degree of concordance between the three SARS-CoV-2 targets for the three WWTPs over the sampling period using Kendall's coefficient of concordance, $W$. Kendall's $W$ ranges from 0 (no agreement) to 1 (full agreement). We observed statistically significant concordance between the three SARS-CoV-2 targets for the three WWTPs (W=0.97 for WWTP-1, W=0.96 for WWTP-2 and W=0.78 for WWTP-3).

WWTP-1 served a small community of around 10,000 people. We normalized SARS-CoV-2 levels with PMMoV, which has been proposed to account for differential dilution and degradation rates over time. in assessing community-wide spread of the disease.

A

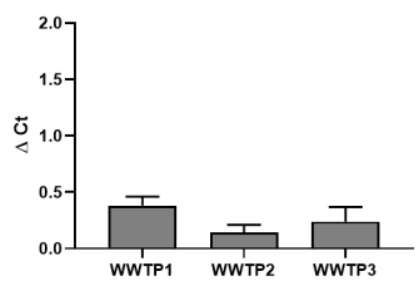

B

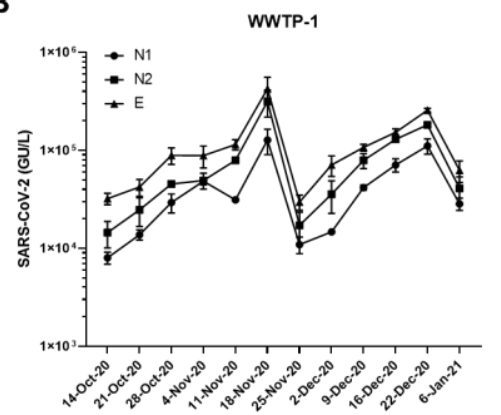

c

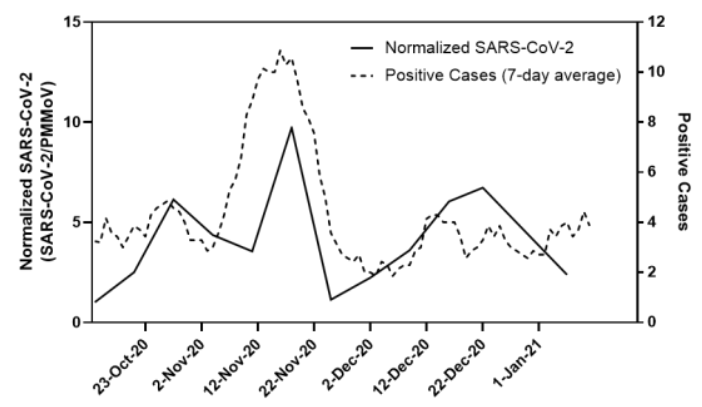

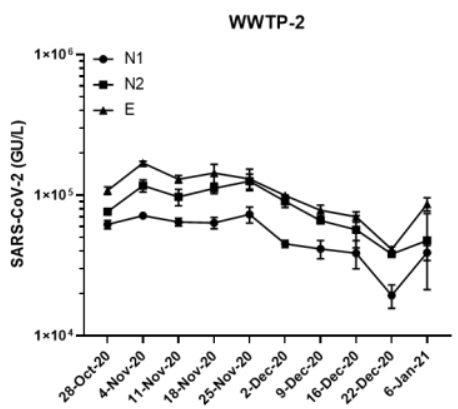

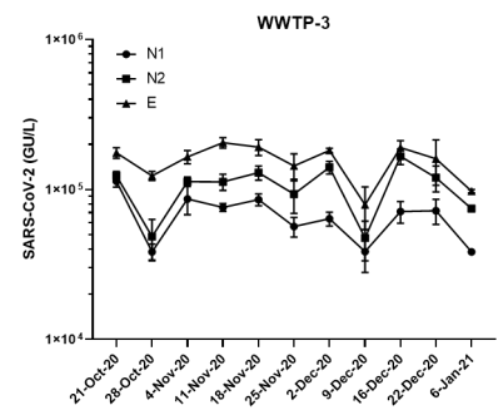


medRxiv preprint doi: https://doi.org/10.1101/2021.05.06.21256753; this version posted May 10, 2021. The copyright holder for this preprint (which was not certified by peer review) is the author/funder, who has granted medRxiv a license to display the preprint in perpetuity.

It is made available under a CC-BY-ND 4.0 International license .

Figure 7. WBE analyses of samples from three wastewater treatment plants in Dane

County, WI. (A) Assessment of PCR inhibitors in nucleic acid isolated from the three

512

WWTP. Results shown are means $\pm \operatorname{SD}(n>30)$

(B) Levels of SARS-CoV-2 analyzed over the

indicated duration with three SARS-CoV-2 targets (N1, N2, E) for the three WWTP.

Results shown are means \pm SD $(n=3)$. (C) Comparison of the normalized SARS-CoV-2 RNA

levels with the 7-day moving average of the new reported cases for the community serving WWTP-1.

\section{Amplicon sequencing of SARS-CoV-2 genetic material in wastewater}

To determine if our direct capture purification method yielded nucleic acid compatible with nextgeneration sequencing, we prepared sequencing libraries with a subset of wastewater samples using a commercially available SARS-CoV-2 amplicon panel and associated library preparation kit ${ }^{46,47}$.

522 For this proof of concept, we focused on three samples: wastewater from WWTP-2 in November of 2020 and January 2021, as well as wastewater collected from WWTP-3 in December of 2020. Because of the

524 proximity of the two collection sites to one another, we reasoned that these samples could be compared

525 broadly for the purpose of identifying SARS-CoV-2 variants, while also demonstrating the robustness of 526 the method to different wastewater treatment regimens from different facilities.

527 We compared total nucleic acid or DNase-treated nucleic acid as input into the library preparation 528 workflow. Most libraries had greater than 1 million reads, but for comparison of depth metrics, the total 529 number of reads was normalized across libraries by randomly subsampling to 650,000 total paired reads.

530 We aligned the subsampled, filtered sequencing reads to the SARS-CoV-2 genome and measured the 531 percentage of filtered reads aligned and the depth of coverage across amplicons tiling the SARS-CoV-2

532 genome (Fig. 8A-B). Samples that were DNase-treated had higher percentage of filtered reads aligning to 533 the SARS-CoV-2 genome and greater depth of coverage compared to total nucleic acid libraries. Because 534 wastewater is a heterogeneous sample, it is not surprising that the amplification reaction resulted in off- 
medRxiv preprint doi: https://doi.org/10.1101/2021.05.06.21256753; this version posted May 10, 2021. The copyright holder for this preprint (which was not certified by peer review) is the author/funder, who has granted medRxiv a license to display the preprint in perpetuity.

It is made available under a CC-BY-ND 4.0 International license .

target amplification. This data shows that DNase treatment of wastewater total nucleic acid improves next-generation sequencing quality from the SARS-CoV-2 amplicon panel tested.

537 We aligned the reads a second time to a combined reference genome containing both SARS-CoV-2 and

538 human reference genomes to examine the proportion of aligned, filtered reads attributable to

539 contamination by human genetic material. Surprisingly, we found that the percentage of filtered reads

540 aligning to the human genome increased after DNase treatment (3.5\%-9.4\% for total nucleic acid and

$5416.3 \%-16.5 \%$ for DNase-treated samples). However, the proportion of non-human contamination reduced

542 by DNase treatment makes this the preferred protocol.

543 Finally, using all available reads, we analyzed the aligned sequencing reads from the DNase-treated

544 samples to look for the presence of previously reported SARS-CoV-2 variants of concern associated with

545 widespread viral strains. The variants that we detected (Supplemental file 1) were consistent with known

546 variants in Dane County, Wisconsin during the sampling period ${ }^{36}$. Virtually all the SARS-CoV-2

547 sequences contained mutations corresponding to Nextstrain clade 20A. Mutations found in Nextstrain

548 clades 20B, 20C, and 20G were also present, though mutations specific to strain 20B were present at

$5492.0 \%$ frequency in January, below the $10 \%$ frequency cutoff we had set for making a positive call.

550 Although merely suggestive due to small sample size, this does correspond to Nextstrain reported data

551 which also suggests a decrease in the prevalence of this strain over the sampling period. More

552 transmissible strains were not observed in this data, consistent with Nextstrain reports for such strains

553 initially appearing in this geographic area approximately 2 months after the sampling period. 
medRxiv preprint doi: https://doi.org/10.1101/2021.05.06.21256753; this version posted May 10, 2021. The copyright holder for this preprint (which was not certified by peer review) is the author/funder, who has granted medRxiv a license to display the preprint in perpetuity.

It is made available under a CC-BY-ND 4.0 International license .

A

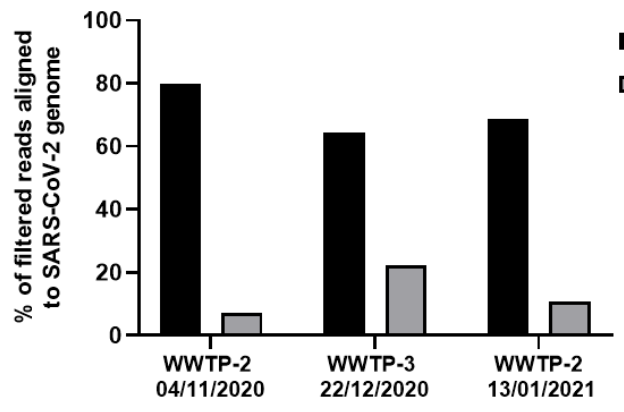

B

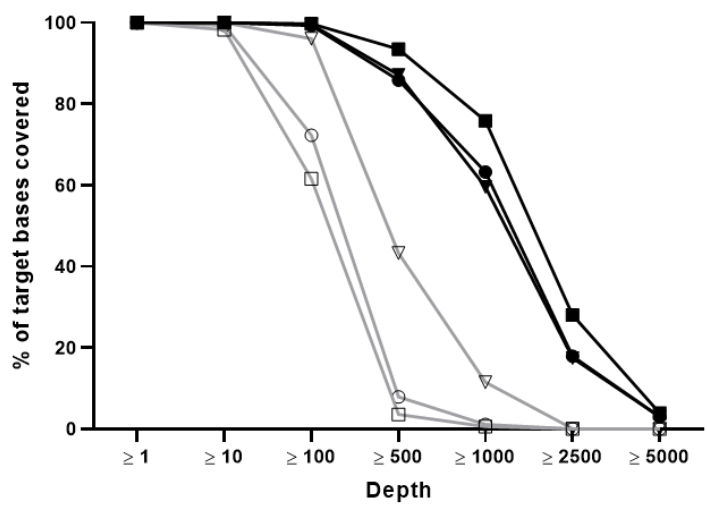

Figure 8. Analysis of wastewater nucleic acid for SARS-CoV-2 sequencing. Nucleic acid

\section{Conclusion}

564 In this study, we describe a convenient, high throughput, robust, and consistent method to directly capture, concentrate, and detect total nucleic acids (TNA) from wastewater using silica based PureYield ${ }^{\circledR}$ 
medRxiv preprint doi: https://doi.org/10.1101/2021.05.06.21256753; this version posted May 10, 2021. The copyright holder for this preprint (which was not certified by peer review) is the author/funder, who has granted medRxiv a license to display the preprint in perpetuity.

It is made available under a CC-BY-ND 4.0 International license .

columns and optimized RT-qPCR. This method offers ease-of-use and minimizes the need for specialized

567 laboratory equipment. In addition, the method achieves consistent recovery rates and significant reduction

568 in RT-qPCR inhibitors.

569 During the course of this study, alternative direct capture methods for extraction of SARS-CoV-2 RNA

570 from wastewater have been published, highlighting the simplicity of the general workflow ${ }^{48}$. Direct

571 capture methods have also been applied in large-scale interlaboratory method assessment studies where

572 they have shown superior and consistent performance over other methods including PEG/NaCl

573 precipitation, centrifugal ultrafiltration, or charged membranes ${ }^{49}$. By using a protease treatment step, we

574 are able to release a significant portion of viral nucleic acid associated with the solids in the wastewater.

575 In addition, chaotropes and alcohols provide an effective nucleic acid binding environment for capture on

576 a silica matrix. The two-step, modular purification strategy described in this work simplifies the

577 workflow for users processing either small or large amounts of wastewater samples. The flexibility of the

578 method and compatibility of the resulting nucleic acid with downstream analysis by RT-qPCR and

579 SARS-CoV-2 sequencing allow for straightforward adoption for WBE-based viral surveillance

580 approaches.

581 Throughout the early course of the COVID-19 pandemic, the ramifications of not having nationwide

582 surveillance systems in place were observed. WBE and clinical diagnostic testing each can provide

583 structured surveillance systems. WBE can complement clinical diagnostic testing by independently

584 confirming prevalence of disease communities and possibly providing an early warning for future viral

585 outbreaks. WBE also provides a low-cost tool to understand community spread in low resource areas.

586 Similar to diagnostic clinical testing, WBE has experimental limitations (uncertainties related to timing

587 and quantities of viral and viral nucleic acid shedding, RNA stability, effect of temperature, and sample

588 processing techniques) that need to be well understood before using acquired data to inform

589 epidemiological and public health efforts around the globe. 
medRxiv preprint doi: https://doi.org/10.1101/2021.05.06.21256753; this version posted May 10, 2021. The copyright holder for this preprint (which was not certified by peer review) is the author/funder, who has granted medRxiv a license to display the preprint in perpetuity.

It is made available under a CC-BY-ND 4.0 International license .

As the COVID-19 pandemic has progressed, SARS-CoV-2 genetic variants have arisen, often leading to

591 increased transmissibility, concern about immune evasion, and subsequent outbreaks ${ }^{50}$. With the

592 emergence of new strains, it will be informative to see how this rapidly evolving method is able to help

593 understand the spread of variants within communities and guide health authorities to take appropriate

594 measures $^{51-53}$.

\section{Data Statement}

Sequencing data are available upon request of the corresponding author.

\section{Acknowledgements}

Amplicon library preparation guidance, basic analysis guidance, and MiniSeq sequencing were provided

by Swift Biosciences, Inc (https://swiftbiosci.com). We thank Paul Muschler for providing valuable

feedback. We acknowledge the staff of Madison Metropolitan Sewage District (MMSD), Village of productive discussions on this topic in these difficult times.

\section{Authorship contribution statement}

607 Subhanjan Mondal: Conceptualization, Data curation, Formal analysis, Supervision, Methodology,

608 Investigation, Roles/Writing - original draft, Writing - review \& editing. Nathan Feirer:

609 Conceptualization, Data curation Formal analysis, Methodology, Investigation, Roles/Writing - original

610 draft, Writing - review \& editing. Michael Brockman: Data curation, Formal analysis, Methodology,

611 Roles/Writing - original draft, Writing - review \& editing. Melanie A. Preston: Investigation, Writing -

612 review \& editing. Sarah J. Teter: Investigation, Writing - review \& editing. Dongping Ma: 
medRxiv preprint doi: https://doi.org/10.1101/2021.05.06.21256753; this version posted May 10, 2021. The copyright holder for this preprint (which was not certified by peer review) is the author/funder, who has granted medRxiv a license to display the preprint in perpetuity.

It is made available under a CC-BY-ND 4.0 International license .

Investigation, Said A. Goueli: Resources, Writing - review \& editing. Sameer Moorji:

614 Conceptualization, Resources. Brigitta Saul: Conceptualization, Resources. James J. Cali: Resources,

615 Supervision, Writing - review \& editing.

616

\section{Declaration of competing interest}

618

All authors are employed by Promega Corporation.
620

621

6221 Zhu, N. et al. A Novel Coronavirus from Patients with Pneumonia in China, 2019. N Engl J Med

623

6242 Hartenian, E. et al. The molecular virology of coronaviruses. J Biol Chem 295, 12910-12934,

625

626

627

628

629

$630 \quad 5$

631

6326

633

634

635

636

637

\section{References}

382, 727-733, doi:10.1056/NEJMoa2001017 (2020). doi:10.1074/jbc.REV120.013930 (2020).

3 Cui, J., Li, F. \& Shi, Z.-L. Origin and evolution of pathogenic coronaviruses. Nature Reviews Microbiology 17, 181-192, doi:10.1038/s41579-018-0118-9 (2019).

4 Zhou, P. et al. A pneumonia outbreak associated with a new coronavirus of probable bat origin. Nature 579, 270-273, doi:10.1038/s41586-020-2012-7 (2020).

5 He, X. et al. Temporal dynamics in viral shedding and transmissibility of COVID-19. Nat Med 26, 672-675, doi:10.1038/s41591-020-0869-5 (2020).

6 Cevik, M. et al. SARS-CoV-2, SARS-CoV, and MERS-CoV viral load dynamics, duration of viral shedding, and infectiousness: a systematic review and meta-analysis. The Lancet Microbe, doi:10.1016/S2666-5247(20)30172-5 (2020).

7 Furukawa, N., Brooks, J. \& Sobel, J. Evidence Supporting Transmission of Severe Acute Respiratory Syndrome Coronavirus 2 While Presymptomatic or Asymptomatic. Emerging Infectious Disease journal 26, doi:10.3201/eid2607.201595 (2020). 
medRxiv preprint doi: https://doi.org/10.1101/2021.05.06.21256753; this version posted May 10, 2021. The copyright holder for this preprint (which was not certified by peer review) is the author/funder, who has granted medRxiv a license to display the preprint in perpetuity.

It is made available under a CC-BY-ND 4.0 International license .

6388 Zhang, Z. et al. Early viral clearance and antibody kinetics of COVID-19 among asymptomatic

$639 \quad$ carriers. 2020.2004.2028.20083139, doi:10.1101/2020.04.28.20083139 \%J medRxiv (2020).

6409 Park, S. K. et al. Detection of SARS-CoV-2 in Fecal Samples From Patients With Asymptomatic

641 and Mild COVID-19 in Korea. Clin Gastroenterol Hepatol, doi:10.1016/j.cgh.2020.06.005

$642 \quad(2020)$.

64310 Day, M. Covid-19: identifying and isolating asymptomatic people helped eliminate virus in

$644 \quad$ Italian village. 368, m1165, doi:10.1136/bmj.m1165 \%J BMJ (2020).

64511 Wang, W. et al. Detection of SARS-CoV-2 in Different Types of Clinical Specimens. JAMA 323,

$646 \quad$ 1843-1844, doi:10.1001/jama.2020.3786 \%J JAMA (2020).

64712 Chen, Y. et al. The presence of SARS-CoV-2 RNA in the feces of COVID-19 patients. $J$ Med

648

Virol 92, 833-840, doi:10.1002/jmv.25825 (2020).

64913 Zheng, S. et al. Viral load dynamics and disease severity in patients infected with SARS-CoV-2

650 in Zhejiang province, China, January-March 2020: retrospective cohort study. BMJ 369, m1443,

$651 \quad$ doi:10.1136/bmj.m1443 (2020).

65214 Wolfel, R. et al. Virological assessment of hospitalized patients with COVID-2019. Nature 581,

653 465-469, doi:10.1038/s41586-020-2196-x (2020).

65415 Han, M. S. et al. Viral RNA Load in Mildly Symptomatic and Asymptomatic Children with

655 COVID-19, Seoul, South Korea. Emerging Infectious Disease journal 26, 2497,

656 doi:10.3201/eid2610.202449 (2020).

65716 Sethuraman, N., Jeremiah, S. S. \& Ryo, A. Interpreting Diagnostic Tests for SARS-CoV-2. JAMA

$658 \quad 323,2249-2251$, doi:10.1001/jama.2020.8259 (2020).

65917 Lorenzo, M. \& Picó, Y. Wastewater-based epidemiology: current status and future prospects.

$660 \quad$ Current Opinion in Environmental Science \& Health 9, 77-84,

661 doi:https://doi.org/10.1016/j.coesh.2019.05.007 (2019). 
medRxiv preprint doi: https://doi.org/10.1101/2021.05.06.21256753; this version posted May 10, 2021. The copyright holder for this preprint (which was not certified by peer review) is the author/funder, who has granted medRxiv a license to display the preprint in perpetuity.

It is made available under a CC-BY-ND 4.0 International license.

66218 Sims, N. \& Kasprzyk-Hordern, B. Future perspectives of wastewater-based epidemiology: Monitoring infectious disease spread and resistance to the community level. Environ Int 139,

66519 Hellmer, M. et al. Detection of pathogenic viruses in sewage provided early warnings of hepatitis A virus and norovirus outbreaks. Appl Environ Microbiol 80, 6771-6781, doi:10.1128/AEM.01981-14 (2014).

66820 Hovi, T. et al. Role of environmental poliovirus surveillance in global polio eradication and 669 beyond. Epidemiol Infect 140, 1-13, doi:10.1017/S095026881000316X (2012). Initiative. J Infect Dis 210 Suppl 1, S294-303, doi:10.1093/infdis/jiu384 (2014). doi:10.1021/acs.estlett.0c00357 (2020).

67623 La Rosa, G. et al. First detection of SARS-CoV-2 in untreated wastewaters in Italy. Sci Total Environ 736, 139652, doi:10.1016/j.scitotenv.2020.139652 (2020).

67824 Ahmed, W. et al. First confirmed detection of SARS-CoV-2 in untreated wastewater in Australia: A proof of concept for the wastewater surveillance of COVID-19 in the community. Sci Total Environ 728, 138764, doi:10.1016/j.scitotenv.2020.138764 (2020).

68125 Peccia, J. et al. Measurement of SARS-CoV-2 RNA in wastewater tracks community infection 682 dynamics. Nature Biotechnology 38, 1164-1167, doi:10.1038/s41587-020-0684-z (2020).

68326 Randazzo, W. et al. SARS-CoV-2 RNA in wastewater anticipated COVID-19 occurrence in a $684 \quad$ low prevalence area. Water Res 181, 115942, doi:10.1016/j.watres.2020.115942 (2020).

68527 Wurtzer, S. et al. Evaluation of lockdown impact on SARS-CoV-2 dynamics through viral 686 genome quantification in Paris wastewaters. 2020.2004.2012.20062679, doi:10.1101/2020.04.12.20062679\%J medRxiv (2020). 
medRxiv preprint doi: https://doi.org/10.1101/2021.05.06.21256753; this version posted May 10, 2021. The copyright holder for this preprint (which was not certified by peer review) is the author/funder, who has granted medRxiv a license to display the preprint in perpetuity.

It is made available under a CC-BY-ND 4.0 International license .

Bofill-Mas, S. \& Rusiñol, M. Recent trends on methods for the concentration of viruses from water samples. Current Opinion in Environmental Science \& Health 16, 7-13, doi:https://doi.org/10.1016/j.coesh.2020.01.006 (2020).

Ahmed, W. et al. Comparison of virus concentration methods for the RT-qPCR-based recovery of murine hepatitis virus, a surrogate for SARS-CoV-2 from untreated wastewater. Sci Total Environ 739, 139960, doi:10.1016/j.scitotenv.2020.139960 (2020).

30 Kitajima, M. et al. SARS-CoV-2 in wastewater: State of the knowledge and research needs. Science of The Total Environment 739, 139076, doi:https://doi.org/10.1016/j.scitotenv.2020.139076 (2020).

31 Pecson, B. M., Martin, L. V. \& Kohn, T. Quantitative PCR for determining the infectivity of bacteriophage MS2 upon inactivation by heat, UV-B radiation, and singlet oxygen: advantages and limitations of an enzymatic treatment to reduce false-positive results. Appl Environ Microbiol 75, 5544-5554, doi:10.1128/AEM.00425-09 (2009).

32 Chen, S., Zhou, Y., Chen, Y. \& Gu, J. fastp: an ultra-fast all-in-one FASTQ preprocessor. Bioinformatics 34, i884-i890, doi:10.1093/bioinformatics/bty560 \%J Bioinformatics (2018).

33 Lander, E. S. et al. Initial sequencing and analysis of the human genome. Nature 409, 860-921, doi:10.1038/35057062 (2001).

34 Kent, W. J. et al. The Human Genome Browser at UCSC. 12, 996-1006, doi:10.1101/gr.229102 (2002).

35 McKenna, A. et al. The Genome Analysis Toolkit: A MapReduce framework for analyzing nextgeneration DNA sequencing data. 20, 1297-1303, doi:10.1101/gr.107524.110 (2010). D493-D496, doi:10.1093/nar/gkh103 \%J Nucleic Acids Research (2004). 
medRxiv preprint doi: https://doi.org/10.1101/2021.05.06.21256753; this version posted May 10, 2021. The copyright holder for this preprint (which was not certified by peer review) is the author/funder, who has granted medRxiv a license to display the preprint in perpetuity.

It is made available under a CC-BY-ND 4.0 International license .

Corman, V. M. et al. Detection of 2019 novel coronavirus (2019-nCoV) by real-time RT-PCR. Euro Surveill 25, doi:10.2807/1560-7917.ES.2020.25.3.2000045 (2020).

Colson, P. et al. Pepper Mild Mottle Virus, a Plant Virus Associated with Specific Immune Responses, Fever, Abdominal Pains, and Pruritus in Humans. PLOS ONE 5, e10041, doi:10.1371/journal.pone.0010041 (2010).

Kitajima, M., Sassi, H. P. \& Torrey, J. R. Pepper mild mottle virus as a water quality indicator. npj Clean Water 1, 19, doi:10.1038/s41545-018-0019-5 (2018).

41 Bivins, A. et al. Cross-assembly phage and pepper mild mottle virus as viral water quality monitoring tools - potential, research gaps, and way forward. Current Opinion in Environmental Science \& Health 16, 54-61, doi:https://doi.org/10.1016/j.coesh.2020.02.001 (2020). Rosario, K., Symonds, E. M., Sinigalliano, C., Stewart, J. \& Breitbart, M. <em>Pepper Mild Mottle Virus</em> as an Indicator of Fecal Pollution. 75, 7261-7267, doi:10.1128/AEM.00410$09 \%$ J Applied and Environmental Microbiology (2009).

43 Schrader, C., Schielke, A., Ellerbroek, L. \& Johne, R. PCR inhibitors - occurrence, properties and removal. 113, 1014-1026, doi:https://doi.org/10.1111/j.1365-2672.2012.05384.x (2012).

44 Bivins, A. et al. Persistence of SARS-CoV-2 in Water and Wastewater. Environmental Science \& Technology Letters 7, 937-942, doi:10.1021/acs.estlett.0c00730 (2020).

Dada, A. C. \& Gyawali, P. Quantitative microbial risk assessment (QMRA) of occupational exposure to SARS-CoV-2 in wastewater treatment plants. Science of The Total Environment, 142989, doi:https://doi.org/10.1016/j.scitotenv.2020.142989 (2020).

Fuqua, J. L. et al. A rapid assessment of wastewater for genomic surveillance of SARS-CoV-2 variants at sewershed scale in Louisville, KY. 2021.2003.2018.21253604, doi:10.1101/2021.03.18.21253604\%J medRxiv (2021).

47 Fontenele, R. S. et al. High-throughput sequencing of SARS-CoV-2 in wastewater provides insights into circulating variants. 2021.2001.2022.21250320, doi:10.1101/2021.01.22.21250320\%J medRxiv (2021). 
medRxiv preprint doi: https://doi.org/10.1101/2021.05.06.21256753; this version posted May 10, 2021. The copyright holder for this preprint (which was not certified by peer review) is the author/funder, who has granted medRxiv a license to display the preprint in perpetuity.

It is made available under a CC-BY-ND 4.0 International license .

48 Whitney, O. N. et al. Sewage, Salt, Silica, and SARS-CoV-2 (4S): An Economical Kit-Free Method for Direct Capture of SARS-CoV-2 RNA from Wastewater. Environ Sci Technol 55, 4880-4888, doi:10.1021/acs.est.0c08129 (2021).

49 Pecson, B. M. et al. Reproducibility and sensitivity of 36 methods to quantify the SARS-CoV-2 genetic signal in raw wastewater: findings from an interlaboratory methods evaluation in the U.S. Environmental Science: Water Research \& Technology 7, 504-520, doi:10.1039/D0EW00946F (2021).

50 Mascola, J. R., Graham, B. S. \& Fauci, A. S. SARS-CoV-2 Viral Variants-Tackling a Moving Target. JAMA 325, 1261-1262, doi:10.1001/jama.2021.2088 \%J JAMA (2021).

51 Crits-Christoph, A. et al. Genome Sequencing of Sewage Detects Regionally Prevalent SARSCoV-2 Variants. 12, e2703-02720, doi:10.1128/mBio.02703-20 \%J mBio (2021). Izquierdo-Lara, R. et al. Monitoring SARS-CoV-2 Circulation and Diversity through Community Wastewater Sequencing, the Netherlands and Belgium. Emerging Infectious Disease journal 27, 1405, doi:10.3201/eid2705.204410 (2021).

53 La Rosa, G. et al. Rapid screening for SARS-CoV-2 variants of concern in clinical and environmental samples using nested RT-PCR assays targeting key mutations of the spike protein. Water Research 197, 117104, doi:https://doi.org/10.1016/j.watres.2021.117104 (2021). 